\title{
A Few Words for Axel Vander: \\ John Banville and the pursuit of deconstruction
}

To read is to understand, to question, to know, to forget, to erase, to deface, to repeat - that is to say, the endless prosopopoeia by which the dead are made to have a face and a voice which tells the allegory of their demise and allows us to apostrophize them in our turn. No degree of knowledge can ever stop this madness, for it is the madness of words. ${ }^{1}$

When Paul de Man's wartime journalism in Belgium for the collaborationist paper Le Soir was unearthed in 1987, four years after his death, deconstruction was placed on trial within and beyond the academy. The scandal revolved around legacy, survival and forgetting, and raised questions about how one might speak, or come after, such an event. In the immediate aftermath, Jacques Derrida reflected that the affair had bequeathed "the gift of an ordeal, the summons to a work of reading, historical interpretation, ethico-political reflection, an interminable analysis". ${ }^{2}$ For Derrida, those who read after de Man are left with a ceaseless labour of judgement, a reckoning with the past that remains a matter of the present and of the future. Derrida sees de Man's life and thought as shaped by two separate but entangled temporalities that unsettle notions of 'before' and 'after': one was a traumatic "prehistoric prelude" in occupied Belgium, the other a "posthistoric afterlife, lighter, less serious" in America. The "war" that de Man endured within himself was lived at "the crossroads of these two incompatible and disjunctive temporalities". The accused is dead, in ashes, with "neither the grounds, nor the means, still less the choice or the desire to respond", leaving us, alone, "to carry his memory and his name in us". ${ }^{3}$ Those who are left behind must live at this crossroads too, reluctant to discount the mature body of work but unable to forget the 
youthful 'error' of the collaborationist articles. This responsibility to the future is a matter of judging, remembering and reckoning with these temporalities.

The de Man affair displaced intellectual debate from de Man's ideas onto his personality and wartime behaviour. This displacement led to a more general assault on deconstruction that legitimated misrepresentation and the exorcism of ghosts that may never have walked. The clamour of judgement gave deconstruction a face and a voice; it could be personalised, classified and, by many, condemned and brought into disrepute. Given that the accused was unable to answer charges, however, this public event constituted a form of aftermath, leaving a case that could not be closed. As Geoffrey Bennington has observed, reflecting upon the "event" of Derrida's death, the process of assessment and setting right that follows a death is a process of neutralising and forgetting. ${ }^{4}$ The event, in Derrida's terms, resists such closure: the event is unpredictable, unprecedented, never finished or rounded with a sleep. Thus, the event of Derrida's reading - and that of de Man - is "not complete, but open for reading and re-reading in the future". 5 The final word on Paul de Man, one might say, is that there can be no final word.

In John Banville's Shroud (2002) and Ancient Light (2012), there may be no final word on, or for, the enigmatic literary theorist Axel Vander, a figure who bears more than a passing resemblance to de Man. Similarly, Banville does not cast final judgement on the evasive actor Alexander Cleave, whose personal life and professional craft become entangled with Vander's legacy in Ancient Light and Eclipse (2000). This legacy involves Cleave's troubled daughter Cass, a character who flits through all three novels, and whose death Cleave must face at the end of Eclipse and attempt to work through in Ancient Light. Banville originally planned Eclipse and Shroud as one book but eventually left Vander for Shroud. ${ }^{6}$ As a result, the links between Cass, her father and Vander are at once sundered and preserved; they are open for re-reading across all three texts, and nothing is laid securely to rest. In 
Eclipse, via a drunken phone call, Vander fleetingly crosses the void, but Cleave "could make out nothing of what he was saying, except that it was something about Cass, and I was still trying to shake my brain awake when he hung up". ${ }^{7}$ Cleave is left with the indecipherable papers that Cass leaves behind, in which he discerns "nothing so definite as a pattern - an aura, rather, a faint flickering glow of almost-meaning". ${ }^{8}$ In Shroud, Cass reveals to Vander that she has uncovered collaborationist war-time journalism in his name while conducting research in Belgium, and Vander assumes she is travelling to Turin to confront and expose him. Cass becomes Vander's lover rather than accuser, however: Cleave subsequently learns she was pregnant at the time of her suicide, but does not know the identity of the "father notto-be". ${ }^{9}$ Ancient Light calls the shades of Vander and Cass but cannot restore these lost connections: even as he seeks some 'elaborately encoded message', Cleave detects only "the shade of a shade"10 in Cass's late writing. Vander's name "seems very like an anagram", ${ }^{11}$ but its decipherment as Alexander $\mathrm{V}^{12}$ constitutes no triumph, no surmounting, of that legacy. The surplus consonant that escapes this merger of names figures a moment of cleaving, a mark of convergence that is also a mark of separation.

This insistent pattern of cleaving, at once involving intimacy and distance, association and disconnection, characterises the unsettling affinity between Vander and Cleave. In Shroud, Vander conceals himself behind layers of disguise to obliterate his past, but his hallucinatory narrative - a form of testimony - summons and must reckon with the ghosts of memory. Vander, now dead, is a spectral presence in Ancient Light, looming over the personal and professional history of his counterpart Cleave. After witnessing Cleave's disgrace on stage, Vander's biographer, the mysterious JB, has recommended Cleave for the lead role in a film about Vander, The Invention of the Past, which is based upon JB's biography of the same name. After his public 'fall', Cleave is summoned to portray another's shame by displacing his own, an act of exposure and expiation that involves retracing the 
path, or following in the footsteps, of Vander. As this discussion will suggest, the pursuit of the dead who shadow the living in Banville's trilogy is also the pursuit of deconstruction.

These intricately interwoven narratives exhibit a fascination with the recondite rites and idiolects of different closed worlds (the academy, the stage, the disturbed mind and, in other novels, science and art more broadly), worlds in which language at once reveals and dissembles, seeks truth and undoes the very foundation of that pursuit. Vander and Cleave are acutely self-conscious narrators who appear to think through, rather than dismiss, the concerns of the "arcane and coded specialism"13 that is deconstruction. To suggest that these novels are 'about' deconstruction, however, would be to invite wider questions about how any writer can represent or account for a word that marks a reading experience not readily reducible to a style, method or theory. Such an accounting procedure, or judicial process, would continually be obliged to change its accounting methods, to continually rewrite its basis in law. Instead, this essay traces how de Man and, in turn, Derrida speak to or in advance of Banville's novels, which in turn apostrophize, rather than condemn, deconstruction. Separated by a decade (a span of time punctuated - another instance of before and after - by the death of Derrida), Shroud and Ancient Light can be said to 'follow' de Man and, more broadly, deconstruction. One might construe 'following', variously, as moving in the wake of, or in belated relation to another; as imitating faithfully, reverentially; as carrying on a legacy or responsibility; as thinking and writing in the manner of de Man; or as pursuing in potentially vengeful fashion. Through the "madness" of a few words - "shroud", "ash", "cleave" - Banville's fictional pursuit of de Man carries on the name in this complex sense of following, one that gives the dead a face and a voice.

Banville can, of course, be regarded as casting belated judgement on the de Man affair - or other scholarly scandals, such as Louis Althusser's murder of his wife - from the mouths of fictional counsels (Cleave in Ancient Light, or Vander himself in Shroud). This would 
align them with novels such as Malcolm Bradbury's Doctor Criminale or Gilbert Adair's The Death of the Author, both published in 1992, or Bernhard Schlink's Homecoming (2008), texts that practice what Richard Klein has termed the science of "DeManology". ${ }^{14}$ As Michael Greaney observes, in these versions of the de Man story, deconstruction, or poststructuralist theory more generally, "has variously become a plagiarists' manifesto, an alibi for charlatans and imposters, a cover story for criminals". ${ }^{15}$ Deconstruction becomes a veiled name for collaboration and ethical relativism. Greaney sees Shroud as "a semi-apocryphal entry in the canon of DeManological fiction", ${ }^{16}$ and Elmer Kennedy-Andrews's recent reading of the text quietly testifies to the persistence of DeManology. Kennedy-Andrews views Vander as "a shifting signifier of indeterminacy and inconclusiveness, endlessly deconstructive and protean", and the novel is treated as an "allegory of redemption", one that cleanses the contamination of theory: "the mechanical methodology of deconstruction is unable to obliterate the eternal mysteries". ${ }^{17}$ As this discussion will demonstrate, however, to locate Banville in the DeManological tradition is a substantial misreading of his work. Shroud and Ancient Light might be said to inhabit rather than account for deconstruction, and to become intimately entangled with their object of pursuit.

Even though it sets out to censure deconstruction, Homecoming may prove an instructive parallel for the way Banville follows de Man. Schlink places a travestied version of deconstruction on trial to examine issues of justice, memory and narrative. The novel rehearses many elements of de Man's 'fall': incriminating war-time journalism, flight from Europe, reinvention as a vaunted scholar, and eventual revelation of a guilty past. John de Baur, the 'criminal' at the centre of this web of evasion and disguise, proves to be an elusive figure that fascinates and repels the narrator Peter Debauer, who gradually discovers de Baur is his father. Peter never finishes his doctoral thesis, "intended to demonstrate that justice is of use only insofar as its claims are formulated and put into practice without concern for 
social utility", and he cannot construct the impersonal system of justice he seeks, growing tired "of the endless words, the words I read, the words I thought and wrote". ${ }^{18}$ Yet it is the slipperiness of words - in a novel of homecoming, read by chance - that enables him to resurrect his father, whom he believed to have died during the Second World War. In his former guise, de Baur was the fervent Nazi Volker Vonlanden (this may have been a pseudonym) who faked his death and eventually escaped to the United States, where he refashioned himself as a student of de Man and a founder of "the deconstructionist school of legal theory". ${ }^{19}$ Peter's personal Odyssey (Homer's poem is an anchoring point for the novel) enables him to shift ideological allegiances from Nazism and Communism to neoliberalism, and to become a prominent commentator on terrorism post $9 / 11$. This ruthless self-interest is reflected in Vonlanden's Iron Rule, formulated during the war years, a rule supplanting the golden rule of law that "forbids one from doing to another what one would not oneself wish to suffer". This rule of "submission" opposes the "very first of all legal rights: the right to defend oneself". Law for Vonlanden rests on this iron rule: "whatever you are willing to take upon yourself you have the right to inflict upon others". ${ }^{20}$ Peter recognises "The Iron Rule" in de Baur's book The Odyssey of Law which proposes, among other things, that "[w]e make our own truths and lies and are responsible for deciding what is true and what is false", and that " $[\mathrm{t}]$ he decision to use evil for the sake of good requires that the decision-maker be willing to bear the brunt of evil". ${ }^{21}$ The iron rule of law, shorn of ethical considerations, seems uncomfortably close to the realisation of Peter's discarded thesis.

In his subsequent research, Peter 'learns' that deconstruction rejects "the notion of reality in favour of the texts we write and read about reality". ${ }^{22}$ This specious account of deconstruction conveniently serves to explain de Baur's academic sophistry and moral abdication in his personal life. The dismayed son, who must bear this tainted legacy, is left to face the madness of words that seem to deny "the notion of reality" and undermine any 
aspiration towards truth. De Baur's secrets are eventually exposed, but not by Peter. A conference held by de Baur's friends highlights "the difficult or terrible or blind or cryptic or recalcitrant wartime texts", but while a "French colleague" discerns " "embers under flickering flames" in these writings, de Baur himself "deconstructs" these comments "with such finesse that it was impossible to censure him for them, or even censure him for refusing to take responsibility for them". ${ }^{23}$ There seems to be no crime, statement or act, that cannot be justified, and the scandal leaves de Baur unscathed. As Jacqueline Rose has argued, however, the novel ignores the turn to deconstruction in critical legal scholarship; this approach draws on deconstruction to attribute the failure of law to "the persistent attempts of the juridical profession throughout history to push morality aside". ${ }^{24}$ It is his ambivalence about precisely this failure that prompts Peter to abandon his thesis, but the narrative at once enables and debars the very mode of thought - deconstruction - that would critique and censure de Baur on his own terms. Rather than exploring the complex relationship between justice, law and language, Schlink attempts to settle the case by establishing the conclusive link between a forgotten Nazi ideologue and a version of de Man.

Yet judgement is suspended in the novel, even if Peter's restlessness seems to abate in the closing pages, as he enters a new phase of responsibility and emotional connection. The longing for an Odysseus with "the tricks and lies of the confidence man" ${ }^{25}$ remains, and the son becomes responsible for deciding what is true and what is false. No further appeal to the law can be made: the father is only to be imagined through a tale of flight, disguise and betrayal, a story in which there are no fixed bonds or attachments, and no iron rules. In short, the truth lies in literature, where Peter first discovered his father. This is indicative of the novel's tendency to unravel - dare one say, deconstruct - its own judgements: it cannot, and must not, "get away from all those words". ${ }^{26}$ Schlink implicitly rehearses de Man's warning 
about "the danger of forgetting the precarious relationship to reality offered to us by words", ${ }^{27}$ a precarious relationship that literature both denies and exposes.

As de Man argues in "The Resistance to Theory", language is granted "considerable freedom from referential restraint" in literature, but this makes language "epistemologically highly suspect and volatile, since its use can no longer be said to be determined by considerations of truth and falsehood, good and evil, beauty and ugliness, or pleasure and pain". Literature is the place "where this negative knowledge about the reliability of linguistic utterance is made available", ${ }^{28}$ To acknowledge the possibility of this "autonomous potential of language" is to free "the discourse on literature from naive oppositions between fiction and reality". Such an account of literariness can be dismissed as "pure verbalism, as a denial of the reality principle in the name of absolute fictions, and for reasons that are said to be ethically and politically shameful". ${ }^{29}$ (It is all-too-tempting to read this as proleptic of the later trials of de Man's work.) For de Man, however, literariness does not escape from 'real life', but discloses a form of truth about language and reality: "Literature is fiction not because it somehow refuses to acknowledge 'reality', but because it is not a priori certain that language functions according to principles which are those, or which are like those, of the phenomenal world". ${ }^{30}$

Banville, in contrast to Schlink, gives words their day in court: he does not rehearse de Man's indictment, but instead engages in an act of thinking on, as Nicholas Royle has put it: a process of thinking about mourning, about what writing consigns to the future. ${ }^{31}$ As Derrida commented in 1983, "I write in order to keep ... the philosopher is above all a guardian of memory". ${ }^{32}$ Shroud and Ancient Light are guardians of memory, bearing witness to, and carrying forward the gift of an ordeal. For all the shadows cast, memories conjured, accounts implicitly settled or masks and voices assumed, Banville reckons with Vander, and with the spectre named deconstruction, in only a few words: shroud, ash, cleave. These are 
words or motifs that, in turn, suggest veiling, burying or severing but that can equally connote preservation, survival and connection. Such words, and their ramifications, testify to the memory work of deconstruction.

\section{Shroud}

As Cass Cleave remarks in Shroud, "so strange, how things strike echoes everywhere", ${ }^{33}$ Many echoes strike between Vander, Alexander Cleave and de Man, but these are sometimes muffled or distorted. At other times, connections take the form of veiled allusions to, or strange affinities with, the thought of de Man and Derrida. Some correspondences between life and fiction are thinly concealed. De Man wrote for Le Soir and Het Vlaamsche Land while Vander writes for Vlaamsche Gazet; its editor is Hendriks, an echo of Henri/ Hendrik de Man; both de Man and Vander have East European partners early in life (Anaide Baraghian and Magda). De Man sheltered a Jewish couple in Belgium, and this is refracted in the scene where Vander returns to the family flat after the mass deportations, and is then sheltered and helped to escape by Max Schaudeine. ${ }^{34}$ Shroud also alludes to many writers dealt with by de Man, and to Nietzsche and Shelley in particular. Vander refers to his landmark essay on "Shelley and Defacement", an obvious echo of "Shelley Disfigured" in The Rhetoric of Romanticism, and his blindness in one eye may evoke the terror of the transfixed eye discussed by Derrida in Memoirs of the Blind. ${ }^{35}$ Cass plunges to her death in Portonovere on the Ligurian coast, where Shelley drowned.

Ancient Light traces the two disjunctive but overlapping temporalities of De Man's life postulated by Derrida, but in reverse order: first, the dangerous, irresponsible thrill of an adolescent affair, then the scarred adulthood of professional failure and the suicide of his daughter. Cleave skirts a parodic academic culture whose shiftiness and imposture appears to 
duplicate rather than uncover the deceptions of Vander, and he finds Vander's biographer JB a striking counterpart of his subject:

Behind the gloss, the studied elegance, the dandified swagger, this is a man racked by fears, anxieties, sour resentments, yet possessed too of an occasional mordant wit and an eye for what one might call the under-belly of beauty. No wonder he was drawn to Axel Vander for a subject. ${ }^{36}$

Cleave is later invited to a seminar by H. Cyrus Blank, the Paul de Man Professor of Applied Deconstruction (there is no such practice) at the University of Arcady, Vander's own institution. He has already encountered the name Blank in JB's biography, and finds that "[t]hese spidery strands of connection, stretching across the world, their clinging touch gives me the shivers. Blank." ${ }^{37}$ One of these spidery connections prompted JB to write the biography, after a chance meeting in Antwerp with Fargo de Winter, emeritus professor of Post-Punk Studies at University of Nebraska, who "unmasked" the fraudulent Vander. De Winter is an obvious anagram of Ortwin de Graef, who uncovered de Man's wartime journalism while working, like Cass Cleave, in the Low Countries. This tale of scholarly dedication offers no morally instructive journey from error to truth, however. De Winter is amused rather than affronted by Vander's fakery, habituated as he is to false trails: "No, sir, you are right, the fair town of Fargo ain't in Nebraska, as so many folk seem to think'”.38 Cleave follows a path that promises revelation, but opens out to nothing.

For all the knowing biographical allusions, the pursuit of proper names draws a more complex blank in Shroud and Ancient Light, where the name is at once a statement of identity, a matter of investment and an act of concealment. In Shroud, the 'real' Axel Vander died in Belgium in the early 1940s, and the narrator, who is Jewish, assumed his friend's name and identity to escape persecution and establish a new life in the United States. It is the 
complex relation to the dead who speak "in us", to what is done and what is suffered, and to writing as one and as two that shadows the novel. The two Vanders share shrouded names: Jew (possibly, in the case of the original Vander) and arrogant, vainglorious anti-semite, collaborationist author and famous critical theorist, Holocaust victim and survivor: the 'later' Vander discovers that the ur-Vander may have been a covert resistance fighter. For Rose, this Vander represents "the most assimilated Jew of them all", ${ }^{39}$ but one perhaps in desperate denial about how he will be named by those who wish his kind to become nameless. Cass's letter to Vander, which threatens to expose his wartime secrets, never reveals any incriminating evidence, since in one sense, there is nothing, or no-one, to expose. Since another Vander authored the articles, the letter as such does not reach its intended addressee, but it is nonetheless a command, a letter of despatch for its recipient:

Whatever plans I might have put in place, there was nowhere farther I could escape to beyond this tawny shore, last edge of what for me was the known world ... that morning I had the certain sense of having crossed, of having been forced to cross, an invisible frontier, and of being in a state forever more would be post-something, would be forever an afterwards. That letter, of course, was the crossing-point. Now I was cloven in two more thoroughly than ever, I who was always more than myself. On one side there was the I I had been before the letter arrived, and now there was this new I, a singular capital standing at a tilt to all the known things that had suddenly become unfamiliar. ${ }^{40}$

This transit point is reached under another's name, a destination of singular displacement. Vander's delirium (he shares Cass's susceptibility to drift into hallucinatory states) while at a conference in Turin self-consciously recalls Nietzsche's time in the city, and the novel's epigraph is taken from The Will to Power: "We set up a word at the point at which our 
ignorance begins, at which we can see no further e.g. the word 'I', the word 'do', the word 'suffer': - these are perhaps the horizon of our knowledge, but not 'truths"". ${ }^{41}$ The word, the name, is a moment of cleaving: a marker of coming together and of distance, of arrival and of absolute separation at a threshold.

The name is also the point at which ignorance begins in Ancient Light. The novel switches between the memory of a childhood romance between the schoolboy Cleave and Mrs Gray, the mother of his best friend, and Cleave's present involvement in the film, which becomes interwoven with his investigation of Cass's final days. Cleave is not aware that Vander was Cass's lover, and was with her in Portovenere when Cass committed suicide; nor does he know that she was carrying his child. Unwittingly, his screen performance gives shape to the shadowy presence that in 'real' life is pursued by a private detective. He also befriends his co-star, Dawn Devonport (a stage name, and called Cora in the film), who attempts suicide during filming and whose psychological vulnerability mirrors that of Cass. Cleave's screen portrayal is made easier by his strange affinity with Vander: he shares "the simple, blank, insupportable fear of being found out", 42 the sense of having one disembodied eye ${ }^{43}$ and a vertiginous fear of falling from a great height:

It is linked in a mysterious way with the feeling that used to come over me occasionally on stage, the feeling of falling somehow into the character I was playing, literally falling, as one might trip and pitch forwards on one's face, and losing all sense of my other, unacting self. $^{44}$

The imitation Vander's intellectual development is an exercise in fabrication and the manufacture of a voice acutely attuned to the "problematics of authenticity". ${ }^{45} \mathrm{He}$ likens himself to the Harlequin, a survivor who is always forgiven, ${ }^{46}$ the supreme ironist, the 
dissembler. He is a weaver of tales about his early suffering, a deft and practised thief, an actor from the ancient world whose mask "is more like his face than his face is":

He takes to wearing the mask at home, when no one is there. It is a comfort, it sustains him; he finds it wonderfully restful, it is like being asleep and yet conscious. Then one day he comes to the table wearing it. His wife makes no remark, his children stare for a moment, then shrug and go back to their accustomed bickering. He has achieved his apotheosis. Man and mask are one. ${ }^{47}$

This is reminiscent of Cleave in Eclipse, where he seeks a "singular essential self hiding, somewhere, under the jumble of discarded masks". ${ }^{48}$ In Ancient Light, Cleave succumbs once more to this strange play of disguise and recognition, dissonance and correspondence: he finds that film acting renders his "actor self" and "self self" into things of "fragments and disjointure", yet this experience is "both strange, and not strange at all". ${ }^{49}$ Like Vander in Shroud, Cleave experiences an hallucinatory cast of characters in Italy when retracing Cass's last days. Vander's story weaves a "certain mephitic spell": "I seemed to see the shadowy first and valid Axel Vander faltering and falling without a sound and his usurper stepping seamlessly into his place and walking on, into the future, and overtaking me, who will presently in turn become a sort of him, another insubstantial link in the chain of impersonation and deceit". ${ }^{50}$ The early and late versions of Cleave's "self self" are entangled in a web of mimicry and imitation: he first glimpses Mrs Gray naked as "a reflection of a reflection of a reflection". ${ }^{51}$ Similarly, in the wake of Dawn Devonport's suicide attempt, the actress reminds him of his troubled daughter: "I felt as if I were gazing into a mirror". ${ }^{52}$ Just as Cleave's own narrative is based on an early secret that is half-revealed, half-obscured, so the restless search for Vander, and simultaneously for Cass, never finds closure: it is "unfinished business". ${ }^{53}$ He does learn the fate of Mrs Gray, but his lack of awareness about 
her true situation exposes the falsity of his memory about the intimate past: the primal scene in which Mrs Gray's daughter catches them in flagrante, and the Gray family leaves town in disgrace that very night, is a fabrication. As Cleave's wife Lydia observes, "not everything means something". ${ }^{54}$ In both novels, the pursuit of truth is haunted by non-equivalence, and these inexact parallels illustrate their obsessive reflections about inauthenticity, duplicity and ironic doublings. Nothing fixes, but so much lingers.

In Shroud, Vander is expected to lecture on the Turin Shroud, but he reads instead his essay “Effacement and Real Presence”. His former lover Kristina Kovacs discerns in this decision an oblique unveiling of Vander's own veiled history, remarking that "They say it is the first self-portrait". ${ }^{55}$ Such a substitution of titles and names is in keeping with his fevered sojourn in Turin: Vander often mistakes the word sindone for signore, misrecognizing himself "in and as the shroud". ${ }^{56}$ When he and Cass try to see the Shroud - she a believer, he a sceptic - the chapel is closed, and they fail to see it in its temporary location. For some, the Shroud is a physical manifestation of the divine, but if it is a fake - as carbon dating suggested in 1988, one year before the novel is set - it is a sacred object that at once shows and conceals, affirms faith and yet self-consciously practices deception. The weightless Vander is at home, and adrift, in this "realm of simulation". ${ }^{57}$ Cass buys a reproduction of the Shroud on imitation parchment and declares to Vander: "It looks like you ... just like you", 58 Here, the inauthenticity of the self-portrait is the very guarantee of its authenticity.

Yet Vander is a shape-shifter who cannot quite slough off his old pelt entirely, nor assume his new mantle with ease. His first book is entitled The Alias as Salient Fact, and he cannot finish the 'first' Axel Vander's study of Coleridge: the act of writing, of giving the dead their due, is caught between writing as one and as two. Every word that he writes or ventriloquizes as Axel Vander, and yet simultaneously not as Axel Vander - who can no longer speak for himself, yet who lives on through his written and remembered words - is a 
crossing-point between past and present, the quick and the dead, guilt and responsibility, between one and the other. The notorious wartime essays are not his, yet he claims ownership, and makes them his responsibility too:

You will not believe me, I suppose, when I say that when eventually it dawned upon my sometimes sluggish understanding that in taking on his identity I had also automatically taken on responsibility for his deeds, I made a pact with myself that in the event of being shown up as an impostor I would claim - wait for it - I would claim that it was I, and not he, who had written those damning articles, and that I had persuaded him to put his name to them because that was the only way that Hendriks would publish them in the Gazet $!^{59}$

This crime is not committed at first hand: the guilt is of intellectual or moral complicity. Even the mature criticism has its hand guided by this ghostly other; this is autobiography as prosopopoeia, its disfiguring language "mute as pictures are mute". ${ }^{60}$ In this sense the Shroud is an allegory of Vander's muteness, speaking as a voice from beyond the grave, even as all of his dead speak in him.

Shoshana Felman detects such a muteness at the core of de Man's later life and work, arguing that de Man "acknowledged silently and processed into thought" the "oblique and muted testimony" of his "early mistake". De Man's mature work is "unspoken testimony that speaks for itself":61 an acknowledgement of the impossibility of giving voice to that which has perished, of giving face to that which has already been subject to such grievous disfigurement. Like the Shroud, those faces and voices survive in their muteness. Banville's pursuit of Vander tells, mutely, of those who survive the fire. The glow of this distant flame, a remainder that in the present faintly illuminates all that has gone before, is evoked in Ancient Light by the enigmatic Fedrigo Sorrán, who shares a late-night bottle of wine with 
Alexander Cleave. He speaks of the "ancient light of galaxies" that flickers across the vastness of space, and the "invisible sea" of dark matter that outlives its death:

'Even now', he said, 'at this table, the light that is the image of my eyes takes time, a tiny time, infinitesimal, yet time, to reach your eyes, and so it is that everywhere we look, everywhere, we are looking into the past. ${ }^{, 62}$

Spent, burnt out, receding into darkness and silence, the past still comes into the light.

\section{Ash}

The Turin Shroud has survived the fire on several occasions; it was damaged by smoke and flames in Cambery Castle in France in 1532, and was saved from fire in Turin in 1997. The Shroud's physical vulnerability to obliteration merely intensifies its transcendent power. Transfiguration by fire is central to Vander's early aesthetic vision: "All must be made over made over or destroyed. We would have, I would have, sacrificed anything to that transfiguring fire ... at whatever cost". The sympathy with those "who turned my family to ash" ${ }^{\text {"3 }}$ rages alongside an unquenchable burning fear felt by Vander and all Jewish people in wartime Belgium. It is why he sees his ideal place as "an anonymous patch of ground, with asphalt, and an oily bonfire smouldering, and vague factories in the distance, some rank, exhausted non-place where I can feel safe, where I can feel at home, if I am ever to feel at home, anywhere". ${ }^{64}$ Ash, immolation, is both destination and the non-place, perhaps in this instance because the non-lieu in French denotes a dismissal of charges. Ash and fire are recurrent motifs in Shroud: there is ash from innumerable cigarettes, the cremation of Shelley is evoked on several occasions, and it eventually transpires that the first Axel Vander's family, like that of his imposter, perished in the East. Fostered families, fostered histories drift towards the flames. The middle section of the novel, which recalls the narrator's life in 
occupied Belgium, shifts constantly between the generality of the Holocaust and its unbearable particularity:

The past, my own past, the past of all the others, is still there, a secret chamber inside me, like one of those sealed rooms, behind a false wall, where a whole family might live in hiding for years. In the silence, in solitude, I close my eyes and hear them in there, the mouse-scuffles of the little ones, the grown-ups' murmurings, their sighs. How quiet they go when danger draws near [...] My eyelids lift. A breath. All gone, all of them; gone. ${ }^{65}$

Gone before they are gone, heard where they are silent: the lost are somehow protected at the moment of utmost peril, sheltered in the intimate remoteness of memory through an act of "commemoratively beautiful mourning". ${ }^{66}$ This survival is, like ash, a material aftermath, something and nothing: residue, testimony and erasure all at once. Ash is both futural and finite: it is at once the trace of the unique event that cannot ramify into generality, and the survival of the work or the event, its precarious remainder. This memory, however fictive, cannot halt the scattering of ash that drifts across Shroud.

From the outset, ash awaits in Ancient Light. Mrs Gray unsuccessfully holds her cigarette out of the car window before Cleave first kisses her; most of the time "the ash blew back in again". ${ }^{67}$ He hopes to make Mrs Gray pregnant, but this anticipated legacy soon turns “to ashes". ${ }^{68}$ Dawn Devonport's tobacco consumption is furtive, rationed but insistent, in tribute to her father's recent death from a forty-a-day habit. It deposits a trail of ash across Cleave's search for answers about Cass in Italy. In the aftermath of her suicide attempt, Devonport exudes a "flat dry odour" ${ }^{69}$ befitting the atmosphere of the hotel in Lerici, where the "whiff" of drains arises as if from "ancient, rotting lungs"70 and whose upholstery "smelt strongly of immemorial cigarette smoke". ${ }^{71}$ This survivor of the flames, her cigarettes 
emitting "sacrificial fumes", ${ }^{72}$ speaks to Cleave from the other side of death, turning the afternoon "to the colour of ash": "I saw something, when I was dead ... something that wasn't like anything". ${ }^{73}$ Cleave's other route to the past must similarly sift the ash. The only living connection to his teenage love affair, Mrs Gray's daughter, Kitty - now Sister Catherine chain smokes, and the family name will die with her. The return to a cherished name comes back only to the greyness of ash.

So, too, ash settles upon any consideration of de Man after the revelation of his wartime writings. Felman cites de Man's editorial introduction to Exercice du Silence in December 1942, a month after his final articles appear in Le Soir. He conceives of the death of the self as a process in which the self carefully "burnt out the dictionaries of his memory". ${ }^{74}$ This (self)immolation, recounted after the event, announces departure and silence, an obliteration and an afterlife, a prosopopoeia of the one who survives the fire, who is transfigured. In Shroud, we might say that the name Vander is ash, the former self transfigured as the new self, one who is still a creature of ash. Ash drifts across Derrida's thought as holocaustic singularity and as finitude, as scattering and dissemination. What he says of the date can stand also for memory and writing in Shroud and Ancient Light: "And so what must be commemorated, at once gathered together and repeated is, at the same time, the date's annihilation, a kind of nothing, or ash. // Ash awaits us". ${ }^{75}$ After every burning, after every departure, there is ash.

\section{Cleave}

What cleaves to us, even as we are cloven from it? In their concern with the singularity of death and its afterlife in eulogy, memory and apostrophe, the three novels that commune with Cass show an affinity with Derrida's works of mourning. They meditate on how, in Derrida's words, to reckon with “those no longer with us but who speak 'in us', and 
the living present of each text carries within it the 'signature of memoirs-from-beyond-thegrave" ${ }^{76}$ Each novel bears witness (there is more than a hint of Dante's Inferno in the narrator's account in Shroud), but every act of witnessing is haunted by guilt and a feeling of separation. In differing ways, Cass, Vander and Cleave are survivors of events, or crimes, not witnessed directly. Vander is absent at a crucial moment in his early life. He receives an anonymous note instructing him to travel by train over the French border on a certain date, then return on the very next train. On his return to his flat, he discovers that his family, and the entire Jewish population, have been transported. This narrator is one who returns from the dead, survives the fire, but the very act of surviving renders him absent at the moment of witnessing. (In this case, to witness 'in person' would be the end of witnessing.) Vander is elsewhere at the moment of departure and eviction, a traveller to nowhere whose disinheritance opens up the future (like the Vander whose name he inherits). The witness to catastrophe is a failure, if to survive is to fail to coincide with the unspeakable, incalculable event. The witness is cloven by survival: carrying, preserving that past, but already displaced at the point of departure. At the end of Eclipse, Cleave has a momentary vision of his dead daughter, but as she fades from view, he reflects that " $[\mathrm{t}]$ he living are too much for the dead". 77

Those who harbour secrets in Ancient Light are failed witnesses in differing ways. The biographer JB, like Cass before him, only has partial knowledge of Vander, and no-one bears public witness to the act that confirms the affair between Cleave and Mrs Gray. Early in the narrative, Cleave speculates that his lover was aware of the possibility of future disgrace:

Perhaps her capacity to conceive of imminent disaster was blunted by a constant awareness of the possibility - the inevitability, as it happened that one day a long time off in the future she would be found out and disgraced not only before her family but in the eyes of the entire town, 
if not the country. ${ }^{78}$

This is a distant echo of the de Man scandal, but in Cleave's case, the 'disgrace' is the product of his own failed witness, and of a failure to read or comprehend the context of his discovery. As we have seen earlier, the moment of revelation is merely an invention of the past: Cleave's version of events is erroneous, and Kitty makes no judgement about the "monkey business". ${ }^{79}$ Kitty was alone when she observed the lovers, not with her friend Marge; she told only her brother Billy, and no-one else; and the family did not leave the town immediately, but more than a month later. By the end of that year, Cleave's heart "healed", but Mrs Gray had died of endometrial carcinoma, and Kitty would never disclose what she had seen. Every witness is absent, and when Cleave 'confesses', it is a confession that finds no crime or sin to confess.

There is another enigmatic act of cleaving in both novels. Each begins and ends by addressing, at an impossible distance and yet in the utmost proximity, an unspecified woman or idealized femininity to whom the narrator cleaves. In Shroud, it is "her voice, in my head" in the opening line, and the narrator's final words are "Why should I have life and she have none? She. She." 80 The air is murmurous with voices and echoes, but who is the "she" who haunts the book? The "she" might be Cass, Vander's dead wife Magda, Kristina Kovacs (dying of cancer in the novel), Vander's mother, an allusion to de Man's mother, who committed suicide, or to the murdered wife of Louis Althusser. Could "she" be a composite of these figures, or an unnamed other? Is "she" sindone (shroud), a feminine noun, so readily interchangeable with signore for Cass? Or is "she" the maternal tongue that speaks, like the dead, in all of us? If "she" is Cass - there are suggestions in the text that this is so - Vander only knows her inner world as "an immemorial, childhood place". ${ }^{81}$ This maternal "she" is another survivor, one to whom all returns, but one who survives through absence, who loses 
herself in every scene, who survives, like ash, as a remainder. As Derrida puts it in The Ear of the Other:

She gives rise to all the figures by losing herself in the background of the scene like an anonymous persona. Everything comes back to her, beginning with life; everything addresses and destines itself to her. She survives on the condition of remaining at bottom. ${ }^{82}$

The tolling of "she" strikes a number of echoes, including Man's early enthusiasm for a "renewed relation" to the Flemish mother tongue, and thus to a "renewed relation to the past'. ${ }^{83}$ It also recalls Derrida's oration for de Man: 'Forgive me for speaking in my own tongue. It's the only one I ever spoke with Paul de Man". ${ }^{4}$ The mother tongue is the one that cleaves, that lets the dead speak in us if only to toll their irrecoverable loss. The "she" in Shroud is also hauntingly suggestive of de Man's reading of "she" in Wordsworth's "A Slumber Did My Spirit Seal" in Blindness and Insight. He traces the stance of a speaker who is no longer vulnerable to irony, whose insight is no longer in doubt, whose stance is a stance of wisdom: "the poem is written from the point of view of a unified self that fully recognizes a past condition as one of error and stands in a present that, however painful, sees things as they really are". ${ }^{85}$ Here is the perspective of the survivor, one who has passed through a refining fire.

In Ancient Light, the woman who cleaves might again be Cass, the yearned-for, lost daughter. In some measure it may also be Cleave's private detective Billie Stryker, whom he comes to regard as a "dramaturg" $"$ guiding the production of his life. The book begins by falling in love with a mother, so "she" may stand for Mrs Gray, dead soon after their affair through the delayed after-effects of childbirth. Her forename, Celia, is hardly uttered, and she occupies an idealised, remote, quasi-maternal role in the narrative. As if to underscore his distancing from the maternal, Cleave does not know his mother's maiden name. ${ }^{87}$ When he 
finds Kitty in the Convent of Our Sacred Mother, a "mother house", he discovers that "I was mistaken about everything". ${ }^{88}$ The moment of departure, or cleaving, from his first love is a false memory, a fabrication of the past, illustrating Cleave's observation on the opening page that "Madam Memory is a great and subtle dissembler". ${ }^{89}$ The most strikingly intense longing for a female presence, but one experienced in the act of crossing a frontier, comes at the end of the novel. Cleave remembers how his childhood self sought solace after his father's death in his mother's bedroom:

Whom now would I love, and who would love me? I listened to my mother snoring. The air in the room was stale from her breath. One world was ending, without a sound. I looked to the window again. The light around the curtain was stronger now, a light that seemed somehow to shake within itself even as it strengthened, and it was as if some radiant being were advancing towards the house, over the grey grass, across the mossed yard, great trembling wings spread wide, and waiting for it, waiting, I slipped without noticing into sleep. $^{90}$

It is an experience of transfiguration, where a cherished affiliation gives way to the uncertainty of the future. This is a past to come. The memory bears witness to a lost moment, but one that has yet to happen; it is less about remembering or forgetting, and more a matter of thinking on.

So, finally, Banville's reckoning with the figure of deconstruction is not final: the name of deconstruction, which is of course "she" in French, the mother tongue, the name of de Man, and now, in our time of reading, the name of Derrida, lives on. As such, Shroud and Ancient Light bear within themselves a certain responsibility to deconstruction, and a related responsibility to the dead that Derrida articulates when bearing witness to de Man: 
Upon the death of the other we are given to memory, and thus to interiorization, since the other, outside us, is now nothing ... death constitutes and makes manifest the limits of a me or an $u s$ who are obliged to harbour something that is greater and other than them; something outside of them within them..$^{91}$

Thus, in Shroud, the taking of another's name is not solely a desperate survival strategy, an act of erasure, an evasion of responsibility. In Ancient Light, Cleave's assumption of roles is a means of making "all my dead alive to me, for whom the past is a luminous and everlasting present". ${ }^{92}$ There is a certain fidelity in both acts, a carrying-forward of the name and of the work. This applies to both Axel Vanders, to Alexander Cleave as mourning father and ruined actor, and to both Paul de Mans: it suggests the ways in which these personae unsettle the before and the after. Even as these novels pursue an elusive, evasive figure who has gone before, it is a pursuit that undoes itself, that finds no-one to arraign. The novels write in the name of the other, appreciating what it means to survive the fire, what it means to cleave. It is how deconstruction reads, and how we might 'read' deconstruction.

\section{Notes}

1. De Man, Rhetoric of Romanticism, 122.

2. Derrida, "Like the Sound of the Sea Deep within a Shell", 639.

3. Ibid., 650.

4. Bennington, 'In the Event', 27.

5. Ibid., 34 .

6. Friberg, "Passing Through Ourselves", 163, n. 2.

7. Banville, Eclipse, 201.

8. Ibid., 210-11. 
9. Banville, Ancient Light, 24.

10. Ibid., 144.

11. Ibid., 54.

12. Jeffery, review of Ancient Light, 19.

13. Banville, Ancient Light, 54.

14. Klein, “De Man’s Resistances”, 285-297.

15. Greaney, Uses of Theory, 82.

16. Ibid., 81 .

17. Kennedy-Andrews, "Representations of the Jew", 323, 324.

18. Schlink, Homecoming, 38.

19. Ibid., 179.

20. Ibid., 116.

21. Ibid., 180.

22. Ibid., 186.

23. Ibid., 258.

24. Rose, review of Homecoming, 22.

25. Schlink, Homecoming, 260.

26. Ibid., 39.

27. Rose, review of Homecoming, 23.

28. De Man, "Resistance to Theory", 10.

29. Ibid., 10, 11.

30. Ibid., 11.

31. Royle, In Memory, 152.

32. Derrida, Points, 146.

33. Banville, Shroud, 135. 
34. The story of Vander's fate in Belgium is reminiscent of Paul Celan's 'escape' in Ukraine.

Celan stayed overnight at a friend's house because of curfew, and when he returned next morning his family home was sealed and his parents had been deported to the East. Celan survived in a labour camp. Banville's radio play Todtnauberg (2006) provides an imagined account of Celan's meeting with Heidegger in his mountain retreat in 1967.

35. Derrida, Memoirs of the Blind, 32-3.

36. Banville, Ancient Light, 81.

37. Ibid., 233.

38. Ibid., 94.

39. Rose, review of Homecoming, 23.

40. Banville, Shroud, 11, 13.

41. Nietzsche, Will to Power, 482.

42. Banville, Ancient Light, 92.

43. Ibid., 211.

44. Ibid., 150.

45. Banville, Shroud, 260.

46. Ibid., 10.

47. Ibid., 286-7.

48. Banville, Eclipse, 51. I was followed by masks on the day immediately prior to delivering a paper on Shroud in Helsinki: most strikingly, in the National Gallery I was confronted by Gino Severini’s "Harlequin” and masks in paintings by Giannino Marchig and Vainno Kunnas.

49. Banville, Ancient Light, 113. 114

50. Ibid., 82.

51. Ibid., 29. 
52. Ibid., 213.

53. Ibid., 243.

54. Ibid., 76.

55. Banville, Shroud, 76.

56. Greaney, Uses of Theory, 79.

57. Friberg, "Exile in Simulation”, 251.

58. Banville, Shroud, 156.

59. Ibid., 236-7.

60. De Man, Rhetoric of Romanticism, 80.

61. Felman, Writing and Madness, 10.

62. Banville, Ancient Light, 172.

63. Banville, Shroud, 223.

64. Ibid., 50.

65. Ibid., 237-8.

66. Kenny, review of Shroud, 19.

67. Banville, Ancient Light, 34.

68. Ibid., 71.

69. Ibid., 152.

70. Ibid., 159.

71. Ibid., 206.

72. Ibid., 243.

73. Ibid., 157-8.

74. Felman, Testimony, 135.

75. Derrida, Acts of Literature, 396.

76. Derrida, Work of Mourning, 2, 13. 
77. Banville, Eclipse, 213.

78. Banville, Ancient Light, 65.

79. Ibid., 239.

80. Banville, Shroud, 405.

81. Ibid., 332.

82. Derrida, Ear, 38.

83. Felman, Testimony, 126.

84. Derrida, Work of Mourning, 72.

85. De Man, Blindness and Insight, 224-5.

86. Banville, Ancient Light, 236.

87. Ibid., 221.

88. Ibid., 237, 238.

89. Ibid., 3.

90. Ibid., 245.

91. Derrida, Memoires for Paul de Man, 34.

92. Banville, Ancient Light, 242.

\section{Bibliography}

Adair, Gilbert. The Death of the Author. London: Heinemann, 1992.

Banville, John. Eclipse. London: Picador, 2000.

Banville, John. Shroud. London: Picador, 2002.

Banville, John. Todtnauberg. Dir. Gemma McMullan. BBC Radio 4, Friday 20 January 2006.

Banville, John. Ancient Light. London: Penguin, 2012. 
Bennington, Geoffrey. "In the Event." In Derrida's Legacies: Literature and Philosophy, edited by Simon Glendinning and Robert Eaglestone, 26-35. London: Routledge, 2008.

Bradbury, Malcolm. Doctor Criminale. London: Secker and Warburg, 1992.

de Man, Paul. “The Resistance to Theory.” Yale French Studies 63 (1982): 3-20.

de Man, Paul. Blindness and Insight: Essays in the Rhetoric of Contemporary Criticism. $2^{\text {nd }}$ Rev. ed. Minneapolis, MN: University of Minnesota Press, 1983.

de Man, Paul. The Rhetoric of Romanticism. New York: Columbia University Press, 1984.

Derrida, Jacques. "Like the Sound of the Sea Deep within a Shell: Paul de Man's War."

Trans. Peggy Kamuf. Critical Inquiry 14, no. 3 (Spring 1988): 590-652.

Derrida, Jacques. The Ear of the Other. Trans. Peggy Kamuf and Avital Ronnell. Edited by Christie V. McDonald. Lincoln \& London: University of Nebraska Press, 1988.

Derrida, Jacques. Memoires for Paul de Man. Rev ed. Trans. Cecile Lindsay, Jonathan Culler, Eduardo Cadava and Peggy Kamuf. New York: Columbia University Press, 1989.

Derrida, Jacques. Acts of Literature. Edited by Derek Attridge. London: Routledge, 1992. Derrida, Jacques. Memoirs of the Blind: The Self-Portrait and Other Ruins. Trans. PascaleAnne Brault and Michael Naas. Chicago and London: University of Chicago Press, 1993.

Derrida, Jacques. Points...Interviews, 1974-1994. Trans. Peggy Kamuf. Edited by Elisabeth Weber. London: Routledge, 1995.

Derrida, Jacques. The Work of Mourning. Ed. Pascale-Anne Brault and Michael Naas.

Chicago and London: University of Chicago Press, 2001.

Felman, Shoshana. Writing and Madness: Literature/ Philosophy/ Psychoanalysis. Rev ed. Palo Alto, CA.: Stanford University Press, 2003. 
Felman, Shoshana, and Dori Laub. Testimony: Crises of Witnessing in Literature, Psychoanalysis and History. New York and London: Routledge, 1992.

Friberg, Hedda. “John Banville’s Shroud: Exile in Simulation.' In Re-Mapping Exile:

Realities and Metaphors in Irish Literature and History, edited by Michael Boss, Irene Gilsenan Nordin and Britta Olinder, 235-254. Aarhus: Aarhus University Press, 2005.

Friberg, Hedda. "'Passing Through Ourselves and Finding Ourselves in the Beyond': The Rites of Passage of Cass Cleave in John Banville's Eclipse and Shroud." Irish University Review 36, no. 1 (Spring/ Summer 2006): 151-164.

Greaney, Michael. Contemporary Fiction and the Uses of Theory: the Novel from Structuralism to Postmodernism. London: Palgrave, 2006.

Jeffery, Ben. Review of Ancient Light. Times Literary Supplement, 20 July 2012: 19. Kennedy-Andrews, Elmer. "Representations of the Jew in the Modern Irish Novel since Joyce.” Irish University Review 43, no. 2 (2013): 307-326.

Kenny, John. Review of Shroud. Times Literary Supplement, 20 September 2002: 19. Klein, Richard. “De Man's Resistances: A Contribution to the Future Science of DeManology.” In Responses: On Paul de Man's Wartime Journalism, edited by Werner Hamacher, Neil Hertz and Thomas Keenan, 285-297. Lincoln \& London: University of Nebraska Press, 1989.

Nietzsche, Friedrich. The Will to Power. Trans. Walter Kaufman and R. J. Hollingsworth. New York: Vintage, 1968.

Rose, Jacqueline. Review of Homecoming. London Review of Books, 31 July 2008: 21-24. Royle, Nicholas. In Memory of Jacques Derrida. Edinburgh: Edinburgh University Press, 2009.

Schlink, Bernhard. Homecoming. [2006] Trans. Michael Henry Heim. London: Weidenfeld 
and Nicolson, 2008. 